\title{
A CASE STUDY ON THE IMPACT OF INTERNSHIP PROGRAM TOWARDS FARMERS INCOME (THE MEMBERS OF THE JAPAN INTERNSHIP ALUMNI ASSOCIATION OF EAST JAVA)
}

\author{
Ahmad Syariful Jamil ${ }^{1}$, Hidayat ${ }^{1}$ and Resti Prastika Destiarni ${ }^{2}$ \\ ${ }^{1}$ National Agricultural Training Center of Jambi, Jambi-Palembang Street Km. 16, Muaro Jambi Regency, \\ Jambi, Indonesia \\ ${ }^{2}$ Universtity of Trunojoyo Madura, East Java, Indonesia
}

DOI: 10.46609/IJSSER.2021.v06i03.024 URL: https://doi.org/10.46609/IJSSER.2021.v06i03.024

\begin{abstract}
One of the programs devoted to address the problem of low farmer regeneration rate was Japan internship program for young farmers. Although it had been launched since 1984, this program had not yet examined its impact on increasing income. Therefore, this study aimed to:

1) Identify the characteristics of program alumni; 2) Analyze the development of program implementation mechanisms; 3) Analyze the impact of the program; and 4) Analyze the policy implications for increasing income. This research was conducted in East Java Province, Indonesia from September to February 2021. In order to answer the research objectives, the Wilcoxon Signed Rank test was used. The results showed that most of the alumni had relatively good characteristics in terms of age, education, training and experience. Based on the recruitment mechanism, the internship program had undergone a transformation from 1984 to 2021. Wilcoxon test results showed that this program had an impacton increasing alumni income after they returned to Indonesia. The role of the government in the sustainability of this internship program is a necessity because this program appears as a manifestation of the government's concern in developing the agricultural sector in Indonesia by increasing the experience and knowledge of farmers through soft skills and technical skills supporting the sustainability of their business. In addition, there is a need for an up-to-date information system related to Japan internship alumni, so that the sustainability of the results of the internship program can be continue.
\end{abstract}

Keywords: Japan Internship program for young farmers, agriculture, regeneration, agricultural policy 


\section{International Journal of Social Science and Economic Research}

ISSN: $2455-8834$

Volume:06, Issue:03 "March 2021"

\section{Introduction}

Sustainable agricultural development relies heavily on the role of human resources (Arvianti et al. 2019) because human resources play an important role in increasing the competitiveness of the agricultural sector. Susilowati (2016) adds that quality human resources committing to building the agricultural sector are needed.

On the other hand, the agricultural sector faces interest decline of the younger generation. The younger generation seems reluctant to work in the agricultural sector. Even it is predicted that there will be a demographic bonus, Indonesia has actually experienced a decrease in the interest of young farmers. Lovitasari et al. (2017), Farhani (2009) and Iqbal et al (2014) add that the number of farmers over 55 years of age has increased in number, while farmers aged 15-24 have continued to decline. In other words, the agricultural sector experiences a scarcity of young workers and leaves behind parents who are still actively working as farmers (Gusnelly \& Riskianingru, 2019). In the long run, this can cause the agricultural sector to become unproductive.

Departing from these problem, the Ministry of Agriculture has made a breakthrough program through an internship program for young farmers to Japan. The internship program for young farmers to Japan is one of the government programs that are considered appropriate to solve problems in the agricultural sector, not only increasing the capacity of young farming human resources, but also as a means of capitalizing knowledge of modern agricultural business management in Japan (Gusnelly \& Riskianingrum 2019). Through this internship program, it is hoped that it will increase the knowledge and enthusiasm of the interns; and is expected to have an impact on the level of farming success. Since its launch to date, there has been no study that focuses on the impact of the Japan internship program for young farmers on the income level of interns after returning to Indonesia. Therefore, we need a research that focuses on examining the impact of the program on income generation. This research aimed to:

1. Identify the characteristics of the alumni of the Japan young farmers internship program

2. Analyze the development of the mechanism for implementing the Young Farmers Internship Program to Japan (1984-2021)

3. Analyze the effectiveness of the Young Farmers Internship Program to Japan in increasingfarm income

4. Analyze the implication of policy for increasing the effectiveness of the internship programfor young farmers to Japan 


\section{International Journal of Social Science and Economic Research}

ISSN: $2455-8834$

Volume:06, Issue:03 "March 2021"

\section{Research Method}

This research was conducted in East Java Province, Indonesia from September to February 2021. This research was a type of quantitative research with the type of cross section data. Respondents in this study were alumni of the Japan internship program for young farmers. Determination of respondents used purposive sampling method with the consideration that the distribution of the respondents location, so that the number of respondents in this study was 34 people.

In order to answer the research objectives, primary and secondary data were used as the basis for analysis. Primary data were collected through interviews using a questionnaire instrument. The primary data included: 1) the characteristics of the internship program alumni; 2) the social and economic conditions of the internship alumni; and 3) income level. Meanwhile, secondary data were obtained from literature search, related agencies and institutions such as farmer groups, farmer group associations and the Agricultural Extension and Human Resources Development Agency. Secondary data obtained in this study were: 1) Regulations related to the Japan internship program mechanism; 2) related literature; and 3) Data on the employment performance of the agricultural sector in Indonesia.

The research data were then analyzed. This research used descriptive statistical analysis (nonprametric test), namely by elaborating the literature and tabulating data based on a questionnaire. In addition, the Wilcoxon Signed Rank test was used to prove the research hypothesis that there were different in the level of farm income before and after participating in the internship program in Japan. Decision making on the Wilcoxon test was obtained by comparing the calculated $Z$ value and the $Z$ table (Nurhalimah, Marwanti \& Irianto 2017; Prajawati, Triharini \& Asmoro 2014). With the criteria if calculated $Z$ value was less than $Z$ table value, then Ho could not be rejected, this meant that there was no difference in the level of income before and after joining the internship program. Conversely, if the calculated $\mathrm{Z}$ value was more than $\mathrm{Z}$ table then HO was rejected, this meant that there was a difference in the level of income between before and after joining the internship program in Japan.

\section{Result and Discussion}

\subsection{The Characteristics of Japan Internship Program Alumni}

Respondents in the study were alumni of the Japan internship program spread across several districts in East Java Province. The characteristics of research respondents included the factors inherent in individuals such as age, level of education, business condition and experience in doing business. Alumni age was one of the important factors determining success in farming. 


\section{International Journal of Social Science and Economic Research}

ISSN: $2455-8834$

Volume:06, Issue:03 "March 2021"

This was because older farmers were generally less responsive to technological changes. Table 1 shows that most of the respondents' alumni were in the productive age range of 21-50 years, with an average of 38 years. This reflects that alumni could manage farming activities well because most of the alumni were still in their productiveage.

The level of education, both formal and informal, is very important in order to change the behavior of program alumni in doing farming. The level of formal education in this study was school education that had been gained by alumni such as primary school, junior high school, senior high school and college. Table 1 shows that the education level of program alumni was still relatively high in which most of the respondents were at the senior high school and bachelor levels with the respective percentages of 47.06 percent and 35.29 percent. In fact, there were as 3 people (8.82 percent) who had Masters education. The relatively high level of alumni education was a logical consequence of the requirements for alumni before leaving for Japan, in which interns had to at least have a high school education. Meanwhile, informal education was categorized by the many trainings attended by internship alumni. Based on informal education, most of the alumni (32 people or 95.12 percent) had attended various informal education (training). The level of education generally correlated with technology adoption, in which higher education tended to increase one's technology adoption.

The experience in farming also contributes to the success of alumni in increasing the scale of their farming. There is a tendency that the longer a person takes to manage farming, the more skilled someone will be in carrying out farming. The farmers' average experience in working in their respective fields was 8.6 years. Most of the alumni were engaged in farming after they return from Japan. Therefore, the farmer's level of experience can be a sufficient condition for increasing the success of alumni's farming.

\subsection{The Development of Implementation Mechanism in Japan Young FarmersInternship Program}

Since the new order era in Indonesia, the agricultural sector has been one of the sectors absorbing a relatively large workforce. This was evidenced by the large contribution of the agricultural sector to Indonesia's gross domestic product. Badan Pusat Statistik (2018) states that in the 1960s the agricultural sector still dominated the formation of national GDP, which was about more than 50\%. This condition is in contrast to the current situation, in which the agricultural sector only contributes about 12 percent of the total national GDP and continues to experience a decreasing trend in the following years.

The structural change in the agricultural sector indicates a shift in the national development priority sector. The government tends to prioritize the manufacturing and service sectors as 


\section{International Journal of Social Science and Economic Research}

ISSN: $2455-8834$

Volume:06, Issue:03 "March 2021"

drivers of the country's economy. This condition is reflected in the large contribution of the two sectors to national GDP. Based on Badan Pusat Statistik (2018), it shows that the contribution proportion of the two sectors reaches $45 \%$ of the total national GDP.

This phenomenon of decreasing role in the agricultural sector is not offset by a decrease in the share of employment in the agricultural sector. Based on Badan Pusat Statistik (2018), the proportion of labor in the agricultural sector from the 1980s to 2010 only changes from 56\% to $43 \%$. This condition indicates that the agricultural sector workforce has decreased but at a relatively slower pace compared to the decline in its role in the economy.

This unconformity phenomenon reflects that labor productivity in the agricultural sector is relatively low compared to other sectors. This has triggered changes in the level of participation of the young generation of farmers, not to be involved as labor in the agricultural sector. The younger generation tends to turn to more promising sectors such as the manufacturing sector, services, etc. As a result of this, the agricultural sector only leaves $60.8 \%$ of farmers over 45 years old with an average education level of elementary school (Wiyono, et al, 2015). Susilawati (2014) adds that the number of workers in the agricultural sector with the age of 35 years old continues to decline each year and the remaining is around $12.9 \%$. This indicates that the agricultural sector has experienced a scarcity of young workers and only old farmers are actively working.

The decline in the interest of the younger generation to work in the agricultural sector is a fact that must be faced by the government. The consequence of this will hamper the government's national development program.

Departing from these various threats, the government through the Ministry of Agriculture has issued a farmer regeneration program. The program is an internship program for young farmers to Japan to study farm management in that country. This program is a form of bilateral cooperation between the Indonesian government, the Ministry of Agriculture and the private sector $(\mathrm{G}$ to $\mathrm{P})$. The aim of the program is to produce agricultural entrepreneurs through providing experiences related to the agricultural system in Japan, so that after returning to Indonesia it is hoped that they can become agents of economic development in the region.

The internship program was first implemented in collaboration between the Government of Indonesia and the Association for International Collaboration of Farmers (AICF), whose territory included Fukui and Niigata. Initially, the recruitment system for prospective interns was under the authority of the Internship Sub-Sector, the Agricultural Training and Extension Education Agency (Diklatluh) of the Ministry of Agriculture, which later changed its name to the Agricultural Extension and Human Resources Development Agency (BPPSDMP). In the early 


\section{International Journal of Social Science and Economic Research}

ISSN: $2455-8834$

Volume:06, Issue:03 "March 2021"

stages of the program, four young farmers were dispatched to Japan by the Education and Training Agency based on recommendations from agricultural extension agents.

In the next stage, the internship cooperation is coordinated by the Japan Agriculture Exchange Council (JAEC) Tokyo, the Gunma International Agriculture Exchange Association (IAEA), Niigata Agriculture Association (NAEC), Niigata and Kumamoto International Agriculture (KIA). The process of submitting internship applications is submitted by Japan farmers to Japan Agriculture (JA), which is then forwarded to organizations such as JAEC, IAEA, NAEC and KIA. Then the Japan farmer association represented by JAEC submitted a request to BPPSDMP as the coordinator.

In the process of recruiting prospective interns, BPPSDMP authorizes 10 Agricultural Training Centers throughout Indonesia to carry out the selection process for prospective interns. The selection process is carried out by 10 Center of Agricluture Training (BBPP) in collaboration with the Agricultural Service, in which the related offices also involve agricultural extension agents. Then the prospective interns then attend technical entrepreneurship training held by 10 BBPP. From this technical training, some of the best interns will be selected which will then be verified by BBPP. After the verification process is complete, prospective interns from 10 BBPP will be apprenticed to Japan Internship Alumni farmers who are members of Japan Internship Alumni Family Association (IKAMAJA). The results of the internship from these farmers will be netted by a number of interns who will then be directed for two weeks in Jakarta by BBPPSDMP before being sent to Japan. Young farmers who are dispatched to Japan will be apprenticed to a landlady who is also an alumni in the United States with a period ranging from 8 to 36 months.

The recruitment mechanism then undergoes another change, in which the role of the IKAMAJA was getting bigger. IKAMAJA not only acts as a trainer in technical entrepreneurship training and as a pre-departure internship location, but also has the role of screening and recommending prospective interns to $10 \mathrm{BBPP}$. In addition, the pre-departure internship location, which was initially only concentrated in one location, then involves 10 successful IKAMAJA farmers in each of the 10 BBPP working areas for internships.

Changes in the structural workforce in Japan in recent years have caused the internship recruitment mechanism to also change. This is due to the scarcity of productive age workersin Japan. This condition makes the internship recruitment process subsequently change based on the Specified Skilled Worker (SSW) framework. The fundamental difference in the new process is at the screening stage, in which at that stage it applies intelligence tests, Japan language and Agriculture Skill Assessment Test (ASAT). Interns who will be dispatched to Japan will later get 


\section{International Journal of Social Science and Economic Research}

ISSN: $2455-8834$

Volume:06, Issue:03 "March 2021"

a Japan SSW visa. Based on the number of interns dispatched, in 2021 itis targeted that as many as 1000 interns will be dispatched to study in Japan. This condition is relatively different compared to previous years, which varies from 8 - 50 people per batch.

\subsection{The Impact of Japan Young Internship Program in Increasing Farming Income}

Cheong (2014) states that the internship experience increases the intern's exposure to practicing skills, improves social relations and increases motivation. This social capital is expected to increase the internship experience in Japan that the interns can internalize and apply in Indonesia in order to increase the scale of their farming. Interns who have returned to Indonesia can continue their farming they left behind during the internship program. Additionally, these interns are expected to become job creators in the agricultural sector who are able to absorb workers in the surrounding environment. Therefore, it is necessary to test the increase in income before and after the return of the internship in carrying out his farming.

The evaluation of the impact of the youth farmer internship program to Japan in increasing farm income is approached by analyzing the level of income before and after participating in the internship program. This is in line with one of the objectives of the implementation of the Japan internship program, namely to increase the farm scale of participants who have returned to Indonesia. The level of income before and after participating in the program is used to measure the impact of the implementation of the internship program.

The results of the data normality test using the Kolmonogoroc-Smirmanov test obtained a pvalue of less than $0.05(<0.05)$ for both variables (Table 1). In other words, the two income variables did not spread normally. Variable abnormalities were caused by outliers in both variables. Sari, Sukestiyarno \& Agoestanto, (2017) state that one of the causes for abnormal data is the presence of outlier data.

Because the two variables were not normally distributed, the statistical test used to compare income level was the Wilcoxon Signed Rank Test. This test was used for interval or ratio type data, but the data did not follow a normal distribution. This is in line with Oktaviani \& Notobroto (2014) and Istikanah \& Achadiyah (2014) who state that if there is data that does not spread normally, then the statistical test that can be used is the Wilcoxon Signed Rank.

The Wilcoxon test results obtained calculated $\mathrm{Z}$ value with the amount of -4,933 with Asymp. Sig. ( 2 tailed) in the amount of less than $0.05(<0.05)$ or the hypothesis Ho was rejected. This means that there was an increase in the income of interns after participating in the internship program for respondent farmers. These result supports the research hypothesis which states that the internship program had a positive impact on the income of interns in East Java. 


\section{International Journal of Social Science and Economic Research}

ISSN: 2455-8834

Volume:06, Issue:03 "March 2021"

Table 2 shows that the average level of income before and after participating in the internship program was IDR 9,317,222/year and 22,998,134/year. The increase in average income supports the results of statistical tests, in which there was an increase in income. In addition, the values of the standard deviation of the two income values were respectively IDR22,998,134 for before the internship and IDR 52,976,433 for after the internship. This value shows the diversity of income level data between before and after joining the program. The relatively low value of the diversity of income values before joining the program indicates that when young farmers registered for the program, they had relatively the same farming scale. On the other hand, the non-uniform value of income after the program reflects thatafter the respondents returned to Indonesia, the scale of farming managed was very diverse.

The higher income for respondents is generally caused by various factors influencing their restarting their farming. This factor also supports the success of respondents in running their business. This is because respondents who have completed the internship program have to start farming that was previously abandoned.

One of the factors for the success of respondents in running their farming is the softskills they get from the internship process they did while in Japan. Softskills here are more about character building, personality due to cultural experience and the value of Japan life. Gusnelly \& Riskianingrum (2019) add that through international exposure, they have the opportunity to interact directly with a family in Japan and with other interns from Asian countries, internship alumni are expected to be able to transform the knowledge they get to be applied in their lives upon their return from Japan. Meanwhile, the hardskills earned during his internship in Japan had relatively little effect on his success in increasing the scale of his business. Based on the results of the interview, it was found that $76 \%$ of the respondents stated that the business sector in Japan was different from the business field they were engaged in upon returning to Indonesia. This reflects that the technical knowledge gained during studying in Japan is generally less correlated with the farming being carried out.

Most of the respondents (around $88 \%$ of respondents) stated that the abilities obtained during internship which could then be applied in Indonesia in general were work ethic; discipline and hard work; managerial; time management and focus. Meanwhile, only about $12 \%$ of the total respondents stated that technical knowledge could be applied to theirbusiness in Indonesia. This is due to a relatively wide technology gap between the Indonesian and Japan agricultural sector. In other words, the technology obtained by interns in Japan could not be applied directly to their farming in Indonesia.

These various facts lead to success, one of which is measured by varying income. The different 


\section{International Journal of Social Science and Economic Research}

ISSN: $2455-8834$

Volume:06, Issue:03 "March 2021"

in conditions in Indonesia also causes not all interns to be successful in running their business, even among them are forced to leave the world of agriculture, Gusnelly \& Riskianingrum (2019). In fact, this is very unfortunate because the government has made a lotof investment in the framework of regenerating farmers. Therefore, a policy reorientation is needed in order to increase the chances of business success of the interns after returning to Indonesia.

\subsection{The Implication of the Policy in Japan Young Farmers Internship Program}

The role of the government in the sustainability of this internship program is a necessity because this program appears as a manifestation of the government's concern in developing the agricultural sector in Indonesia by increasing the experience and knowledge of farmers through soft skills and technical skills supporting the sustainability of their business. Basically, the government must be able to build an integrated system between the programs provided by the internship program and the business conditions of the interns. The government must also involve the central government in coordinating follow-up activities for Japan internship because the scope of work of these alumni is the place where alumni come from, not only the central government but local governments must also provide opportunities for these internship alumni to contribute to the agricultural sector in their regions so that the transfer of knowledge occurs and the regional agricultural sector can develop.

So far, the implementation of this internship program is the responsibility and the majority of it is the role of the central government. The local government does not yet have a role in implementing this internship program. However, when the interns return to Indonesia, they will return to the regions and apply what they get in their respective regions. This is the gapin this internship program. The central government conducts selection until departure. After the interns return, they will be immediately handed over to their respective regions and the central government, in this case the Ministry of Agriculture, will not interfere anymore. The central government must build a system integrated with local governments so that interns can actively contribute to agricultural development in their home regions. The system must be able to facilitate alumni for various soft skills and technical abilities to other farmers who do not participate in the internship program.

The government must also be able to include or create a sustainable activity to facilitate these internship alumni so that it can be seen that this internship program runs effectively and provides impact not only for internship alumni but other communities engaged in the agricultural sector. These activities can be in the form of exhibitions, market matching, business matching as well as technical and soft skills trainings which later on, these internship alumni can participate and become trainers in the training. The initiation of these activities is not only limited to the 


\section{International Journal of Social Science and Economic Research}

ISSN: $2455-8834$

Volume:06, Issue:03 "March 2021"

activities of the central government but also activities in the regions.

In addition, there is a need for an up-to-date information system related to Japan internship alumni, so that the sustainability of the results of the internship program can be continued. This data collection is also needed to trace the development of the activities of alumni and beneficiaries of this Japan internship program.

\section{Conclusion}

The main respondents in this study were alumni of the Japan internship program from East Java Province. They were all scattered in various districts in the province. The average age of these alumni was 38 years with the majority of their education level of high school and bachelor degree, 95 percent of whom also had non-formal education provisions in the form ofparticipation in training before being selected to participate in this internship program. This relatively high level of education is a consequence of alumni requirements, then the supportof the existence of non-formal education will encourage the success of alumni in participating in the internship program, so that they can increase the scale of their farming after returningto Indonesia. This is also supported by the tendency that experience affects the skills of a farmer. In its development, the agricultural sector is a sector that accounts for the largest percentage of the workforce in Indonesia, although there is a tendency to decline in its percentage due to its focus on development in the industrial sector. The still role of the agricultural sector does not mean that there are no problems that arise in it, especially in the workforce, because labor is one of the problems. The problem arising is related to the increasing scarcity of young workers in the agricultural sector and only workers who are nearing the end of age and even no longer productive age work in this sector. The existence of this internship program is a solution to increase the interest of young workers to move in the agricultural sector. The purpose of this internship program is to produce agricultural entrepreneurs through providing experiences related to the agricultural system in Japan, so that after returning to Indonesia it is hoped that they can become agents of economic development in their region. Throughout the course of this internship program, there have been various changes in the recruitment process, which in the end the IKAMAJA (Japan Internship Alumni Family Association) currently has an important role not only as a trainer intechnical entrepreneurship training and as a pre-departure internship location, but also has the role of conducting screening and recommending prospective interns to BBPP. Changes occurring in the recruitment process and the role of stakeholders in it are also influenced by structural changes in the workforce occurred in Japan. Even there have been several changes, the existence of this internship program has had a positive impact on alumni or farmers who are sent as internships to Japan because all the knowledge and experience that interns get while in Japan are expected to increase the scale of their farming. Internship alumni 


\section{International Journal of Social Science and Economic Research}

ISSN: $2455-8834$

Volume:06, Issue:03 "March 2021"

can continue their farming which is previously abandoned during the internship program and are expected to become job creators in the agricultural sector who are able to absorb labor in the surrounding environment. In addition, the existence of this program can also increase income for alumni, in which this income increase is an approach to implementing the objectives of the internship program. The results of the data analysis indicated that the internship program had a positive impact on the income of interns in East Java. However, there was a difference in the income value of alumni due to the diversity of business scale management. One of the success factors of respondents in carrying out their farming experience from Japan was the softskills they got from the internship process they did while in Japan, but it turned out that the business sector in Japan was different from the business field that they were involved in when they returned to Indonesia. This reflects that the technical knowledge gained during studying in Japan was generally less correlated with the farming being carried out. Even it was different, the abilities obtained during internship that could be applied in Indonesia in general were work ethic; discipline and hard work; managerial; time management and focus. Based on these results, it can be concluded that the success of the program as measured by income gives varying results, so there is a need for a central role for the government as aform of follow-up to this Japan internship program. The government must be able to build an integrated system between the programs provided by the internship program with the business conditions of the interns, the government must also involve the central government in coordinating the follow-up of Japan internship because the scope of work of these alumniis the area of origin of the alumni, not only the central government but local governments must also provide opportunities for these internship alumni to contribute to the agricultural sector in their regions, so that the transfer of knowledge occurs and the regional agricultural sector can develop. In addition, there is a need for an up-to-date information system related toJapan internship alumni, so that the sustainability of the results of the internship program can be continue.

\section{Acknowledgement}

Authors would like to thank the Sumitomo Foundation Japan and Agricultural Training Center of Jambi, those which have provided an opportunity and funding to conduct field research amid the pandemic Covid-19.

\section{References}

[1] Arvianti, E. Y., Masyhuri, Waluyati, L. R.\& Darwanto, D. H. 2019. Gambaran Krisis Petani Muda di Indonesia. Agriekonomika, 8(2): 168-180. https://doi.org/10.21107/agriekonomika.v8i2.5429.

[2] Badan Pusat Statistik. 2018. Data Tenaga Kerja Berdasarkan Lapangan Kerja. BPS: Jakarta. 
International Journal of Social Science and Economic Research

ISSN: 2455-8834

Volume:06, Issue:03 "March 2021"

[3] Cheong, A. L. H., et al. 2014. Internship Experience: An in-Depth Interview aong Interns at a Learning Institution. Social Behavioral Science, 123: 333-343.

[4] Farhani, A. 2009. Motivasi Sosial Ekonomi Petani Beralih Pekerjaan dari Sektor Pertanian ke Sektor Industri Kerajinan Mebel di Desa Serenan, Kecamatan Juwiring, Kabupaten Klaten. [Skripsi]. Fakultas Pertanian, Universitas Sebelas Maret.

[5] Gusnelly, \& Riskianingrum, D. 2019. Pemagangan Pemuda Tani Indonesia ke Jepang: Periode 1984-2016. Patrawidya, 20(1): 19-40.

[6] Iqbal, M., Hidayat, D., Saputra, Y. H. \& Prasetyo, B. 2014. Eksistensi dan Dinamika Transformasi serta Tipologi Petni Skala Kecil. Pusat Sosial Ekonomi dan Kebijakan Pertanian. Jakarta: Badan Litbang Pertanian Kementerian Pertanian Jakarta.

[7] Istikanah, \& Achadiyah, B. N. 2014. Analisis Perbandingan Kinerja Keuangan dengan Pendekatan Income Statement dan Value Added Statement pada Unit Usaha Syariah. Jurnal Nominal, 3(2): 14-24.

[8] Lovitasari, n. M., Diartam I. K. S. \& Suryawardani, I. G. O. 2017. Persepsi Generasi Muda terhadap Minat Bertani di Kawasan Pariwisata Tanah Lot (Kasus Subak Gadon III, Tabanan). Jurnal Agribisnis dan Agrowisata, 8(4).

[9] Nurhalimah, Marwanti, S. \& Irianto, H. 2017. Analisis Dampak Pembangunan Pelabuhan Perikanan Pantai di Tamperan Kecamatan Pacitan Kabupaten Pacitan terhadap Kondisi Sosial Ekonomi Masyarakat Sekitar. Agrista. 5(1): 191-203.

[10]Prajawati, Y. K., Triharini, M. \& Asmoro, C. P. 2014. Meningkatkan Perilaku Cuci Tangan Melalui Metode Bernyanyi. Jurnal Pediomaternal, 3(1): 9-15.

[11]Sari, A. Q., Sukestiyartno, Y. L. \& Agoestanto, A. 2017. Batasan Prasayarat Uji Normalitas dan Uji Homogenitas pada Model Regresi Linear. Unnes Journal of Mathematics, 6(2): 168-177.

[12]Susilawati, S. H. 2014. Attracting the Young Generation to Engage in Agriculture. Jeonju, Korea: FFTC- RDA International Seminar.

[13] Susilowati, S. H. 2016. Femomena Penuaan Petani dan Berkurangnya Tenaga Kerja Muda serta Implikasinya bagi Kebijakan Pembangunan Pertanian. Forum Penelitian Agro Ekonomi, 34(1), 35-55. 
International Journal of Social Science and Economic Research

ISSN: 2455-8834

Volume:06, Issue:03 "March 2021"

[14]Wiyono, S. et.al. 2015. Kajian Regenerasi Petani pada Keluarga Petani Padi dan Hortikultura, Koalisi Rakyat untuk Kedaulatan Pangan (KRKP), Bekerjasama dengan: DItektorat Kajian Strategis dan KebijakanPertanian, Institut Pertanian Bogor. 